\title{
Prey, management and landscape requirements of an endangered population of the Woodlark Lullula arborea in Southwest Germany
}

\author{
Verena Rösch $^{1}$ D $\cdot$ Pascal Aloisio $^{1}$ D $\cdot$ Martin H. Entling ${ }^{1}$
}

Received: 27 March 2020 / Revised: 23 December 2020 / Accepted: 30 January 2021 / Published online: 14 February 2021

(c) The Author(s) 2021

\begin{abstract}
Vineyards can be valuable habitats for biodiversity conservation. For example, in Rhineland-Palatinate (Germany) over a third of the state's critically endangered Woodlark (Lullula arborea) population breeds in vineyards along the western margin of the Upper Rhine Valley. We here aim to elucidate how local ground cover management, food availability and the proximity to settlements affect territory selection by this bird species in the region. As climate, site conditions and management differ greatly from more continental or Mediterranean wine-growing areas, conditions for Woodlark conservation may differ as well. We compared 26 Woodlark territories in vineyards with 26 nearby reference areas from which Woodlarks were absent. We recorded vineyard ground cover in the inter-rows (\% cover) as well as vegetation height and composition (forbs vs. grasses). Arthropods were sampled using pitfall traps, since they are the main food resource of Woodlarks during the breeding season. In addition, the distance to built-up areas was measured. The vegetation in Woodlark territories was shorter (mean 14.2 vs. $19.6 \mathrm{~cm})$ and more dominated by forbs (39\% vs. $27 \%$ cover) than in absence areas. The vegetation cover in the inter-rows had no effect on Woodlark territory presence or absence. Woodlarks also favoured areas with a higher abundance of arthropods (mean abundance 69.1 vs. 57.5) and a greater distance to built-up areas (mean distance 554 vs. $373 \mathrm{~m}$ ). We conclude that to promote the Woodlark in wine-growing areas, short, forb-rich swards should be created, facilitating arthropod detectability. This is likely to require low levels of nitrogen fertilization since fertilizers favour tall-growing grasses that outcompete forbs. Pesticide applications should be kept at a minimum to enhance arthropods as the main food source for Woodlarks and their chicks. In addition, the expansion of settlements into breeding areas of Woodlarks should be avoided.
\end{abstract}

Keywords Insects $\cdot$ Resource availability $\cdot$ Spiders $\cdot$ Sward structure $\cdot$ Territory selection $\cdot$ Vineyard management

\section{Zusammenfassung}

Ansprüche einer gefährdeten Population der Heidelerche Lullula arborea in Südwestdeutschland an Nahrungsverfügbarkeit, Bewirtschaftung und Landschaft

Weinberge können im Naturschutz eine wichtige Rolle spielen. In Rheinland-Pfalz (Deutschland) brütet beispielsweise mehr als ein Drittel der Population der in diesem Bundesland vom Aussterben bedrohten Heidelerche (Lullula arborea) in den Weinbergen am Westrand des Oberrheintals. Ziel dieser Studie ist herauszufinden, wie sich die Bewirtschaftung der Bodenvegetation, die Nahrungsverfügbarkeit und die Nähe zu Ortschaften auf die Revierwahl der Heidelerche in der Region auswirken. Da sich das Klima, die Standortbedingungen und die Bewirtschaftung stark von kontinentalen und mediterranen

Communicated by T. Gottschalk.

Verena Rösch

roesch@uni-landau.de

Pascal Aloisio

pascalaloisio@gmail.com

Martin H. Entling

entling@uni-landau.de

1 iES Landau, Institute for Environmental Sciences, University

of Koblenz-Landau, Landau, Germany 
Weinbaugebieten unterscheiden, können sich auch die Anforderungen an den Schutz der Heidelerche unterscheiden. Wir haben 26 Heidelerchenterritorien mit 26 nahegelegenen Referenzgebieten verglichen, in denen die Heidelerche nicht vorkam. Wir erfassten die Bedeckung, Höhe und Zusammensetzung (Kräuter vs. Gräser) der Vegetation zwischen den Rebzeilen. Arthropoden, die die Hauptnahrung der Heidelerche während der Brutzeit darstellen, wurden mit Hilfe von Bodenfallen erfasst. Zudem wurde die Entfernung zur nächsten Ortschaft ermittelt. In den Territorien der Heidelerche war die Vegetation niedriger (im Mittel 14.2 vs. $19.6 \mathrm{~cm}$ ) und stärker von Kräutern dominiert (Deckung 39\% vs. 27\%) als in den Referenzgebieten. Die Vegetationsbedeckung zwischen den Rebzeilen hatte keinen Einfluss auf die Wahl der Territorien. Heidelerchen bevorzugten Bereiche mit einer höheren Arthropodenverfügbarkeit (im Mittel 69.1 vs. 57.5 Individuen) und einer größeren Entfernung von Ortschaften (mittlere Distanz 554 vs. 373 m). Heidelerchen lassen sich im untersuchten Weinbaugebiet durch eine niedrige und krautreiche Bodenvegetation fördern, die die Suche nach Arthropoden erleichtert. Dies erfordert eine Beschränkung in der Stickstoffdüngung, da Düngung hochwachsende Gräser fördert, die Kräuter verdrängen. Die Anwendung von Pflanzenschutzmitteln sollte auf ein Minimum begrenzt werden, um die Verfügbarkeit von Arthropoden, die die Hauptnahrungsquelle der Heidelerche und ihrer Jungen darstellen, zu erhöhen. Zudem sollte die Ausdehnung von Ortschaften in Brutgebiete der Heidelerchen vermieden werden.

\section{Introduction}

On a global scale, there often is a trade-off between high agricultural yields and biodiversity conservation (Foley et al. 2005; Hanspach et al. 2017). While agricultural intensification has led to major increases in food production (Matson et al. 1997) biodiversity is declining at an unprecedented rate due to increases in management intensity including monocropping, mechanization, the use of agrochemicals and removal of semi-natural habitat elements (Sala et al. 2000; Hallmann et al. 2017; Leather 2018; Møller 2019). In line with this, vineyards have become one of the most intensively managed agro-ecosystems due to frequent pesticide applications, soil tillage and landscape simplification (Viers et al. 2013). Although on a European scale, vineyards only cover $3.5 \%$ of agriculturally used land, pesticide use amounts to $18 \%$ of overall applications (European Commission 2007). With the arrival of downy and powdery mildew (Plasmopara viticola, Uncinula necator) from North America in the late nineteenth century, usually more than ten fungicide applications per season became necessary to maintain high yields as well as wine quality (Kassemeyer and Berkelmann-Löhnertz 2009; Kolb et al. 2020). Fungicides can have negative effects on non-target arthropods living in vineyards including pest species and their natural enemies (Pennington et al. 2018). In addition, insecticides may be applied, and herbicides to reduce competition for water and nutrients between vines and ground vegetation (European Commission 2007).

Apart from intensive agricultural management, vineyard areas are often considered as aesthetically attractive and are thus frequently used for recreational purposes such as hiking, cycling or dog walking, both by local residents and tourists. This can lead to conflicts between recreational access and wildlife conservation (Bötsch et al. 2018; Maslo et al. 2018). In this context, the close vicinity of settlements is likely to be subject to more frequent disturbances than more distant areas (Mallord et al. 2007). Disturbances can e.g. affect habitat use, territory selection and subsequent reproductive success of animal species (Bötsch et al. 2017; Coppes et al. 2017).

Nevertheless, despite this high management intensity and recreational use, vineyards can offer attractive habitats for a range of specialised species, including the Woodlark ( $\mathrm{Lul}$ lula arborea (Linnaeus, 1758), Passeriformes, Alaudidae) (Verhulst et al. 2004; Pithon et al. 2016; Bosco et al. 2019). This short-distance migratory bird occurs in semi-open, sparsely vegetated habitats including heaths, vineyards, orchards, light forests, windfall areas, clearings and military training areas (Bauer et al. 2005; Gedeon et al. 2014). During the breeding season, Woodlarks are mostly insectivorous, while during the rest of the year they also consume plants and seeds (Snow and Perrins 1998; Bauer et al. 2005).

Globally, the Woodlark is classified as 'least concern' and even increasing, with between 1.3 and 3.3 million breeding pairs throughout its European range (BirdLife International 2004; Sirami et al. 2011). In Germany, however, there are contrasting population trends: in the East the species has recently been showing a positive population trend due to EU land set-aside schemes and secondary habitats in postmining landscapes (Gedeon et al. 2014; Grüneberg et al. 2015). In the western part of the country, it is declining due to agricultural intensification and afforestation on the one hand, and abandonment of marginal lands on the other (Gedeon et al. 2014; BirdLife International 2015; Grunwald 2017). Therefore, in the federal state of Rhineland-Palatinate in the west of Germany the Woodlark is listed as critically endangered (Simon et al. 2014). About half of the state's remaining 200-300 pairs breed in one large military training area while another stronghold is in the vineyards in the Palatinate, Germany's largest wine-producing region, notably in the Haardtrand area west of the city of Landau (Grunwald 2017).

Unlike in the south of Europe where vineyards are often kept completely bare to prevent resource competition of 
vines with the ground vegetation (Arlettaz et al. 2012; Winter et al. 2018; Rollan et al. 2019), in most Palatinate vineyards ground vegetation is present, i.e. during the breeding season of the Woodlark at least every second inter-row between the vines is vegetated.

We here aim to elucidate how different vineyard management practices, resource availability (arthropods, dicotyledonous forbs) and proximity of human settlements affect Woodlark territory selection. To our knowledge, this is the first study investigating Woodlark habitat preferences in vegetated vineyards of the Atlantic Central European agroclimatic zone. We hypothesised that (1) the height, cover and composition of the ground vegetation (Arlettaz et al. 2012), (2) arthropod availability (Bosco et al. 2019) as well as (3) the distance to built-up areas (Mallord et al. 2007; Bosco et al. 2020) determine the incidence of Woodlark territories.

\section{Methods}

\section{Study area}

The study area is located in south-western Germany in the federal state of Rhineland-Palatinate. The Palatinate is the largest wine-producing region in Germany. It is situated at the western margin of the Upper Rhine Valley, which is characterised by fertile loess soils, a mean annual rainfall of $675 \mathrm{~mm}$ (Landau), warm summers (average temperature in July $18.8^{\circ} \mathrm{C}$ ) and mild winters (average temperature in January $0.7{ }^{\circ} \mathrm{C}$, https://de.climate-data.org), and widespread intensive agriculture. The study sites were situated in the vineyards along the Haardtrand west of the city of Landau between the villages of Burrweiler in the North $\left(49^{\circ} 15^{\prime} 19.6^{\prime \prime} \mathrm{N}, 8^{\circ} 04^{\prime} 32.0^{\prime \prime} \mathrm{E}\right)$ and Göcklingen in the South $\left(49^{\circ} 09^{\prime} 40.7^{\prime \prime} \mathrm{N}, 8^{\circ} 00^{\prime} 55.9^{\prime \prime}\right.$ E, Fig. 1) where Woodlarks are known to occur (Grunwald 2017). In total, the study area covered about $54 \mathrm{~km}^{2}$.

\section{Study design}

In spring 2018 we identified 26 Woodlark territories $(0.7-13.2 \mathrm{ha}$, mean $=4.9 \mathrm{ha} \pm 3.7 \mathrm{SE})$ as well as 26 nearby areas where Woodlarks were absent (absence areas, 3.5-10.6 ha, mean $=6.1$ ha \pm 1.6 SE, Fig. 1 ; Table 1). To identify Woodlark territories, the study area between Burrweiler and Göcklingen was divided into six sub-areas of $7-10 \mathrm{~km}^{2}$ (Fig. 1). Each sub-area was visited four times each between the beginning of April and the beginning
Fig. 1 Geographic location of Woodlark territories (filled triangles) and absence areas (unfilled triangles) in the vineyards at the Haardtrand west of Landau in southern Rhineland-Palatinate. The study area is outlined by a black line. Woodlark breeding is concentrated within these first $1-3 \mathrm{~km}$ of foothills along the Palatinate Forest. The inset map on the upper right side of the figure shows the six sub-areas that were used for territory mapping

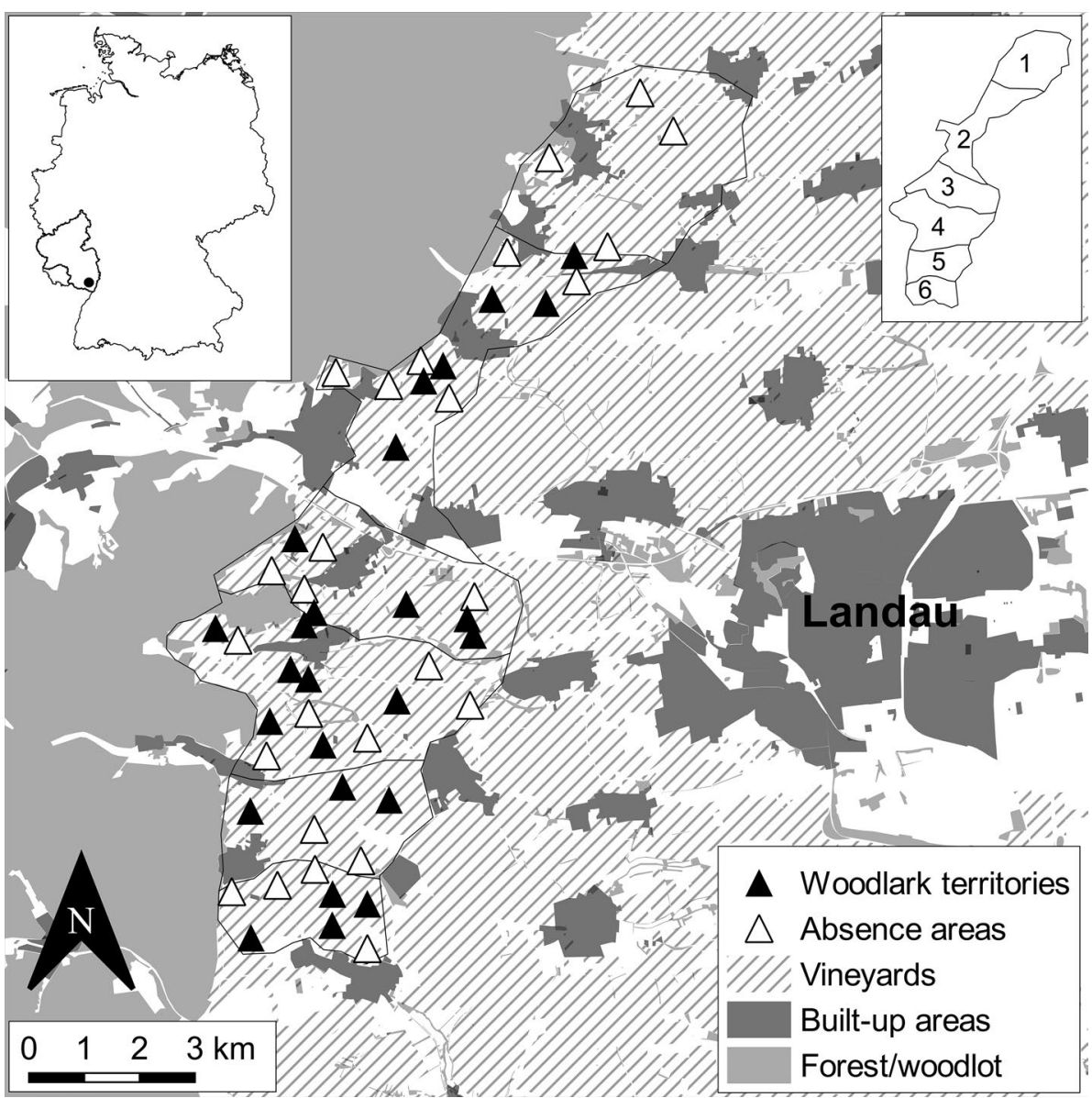


of May 2018, leaving at least seven days between visits. This period coincides with the main singing activity of Woodlarks (Südbeck et al. 2005). The birds were surveyed from sunrise to about five hours after sunrise. We walked on vineyard paths, thereby surveying the entire area. The starting point was changed in each survey. If the species was not directly observable, every $100-150 \mathrm{~m}$ both its call and song were played up to three times from the speakers of a cell phone. The exact location, movement and behavior of each bird were marked on aerial photographs. Fieldwork was only carried out during dry and calm weather. Only areas where Woodlarks were recorded at least twice over the four-week period were classified as territories. After the fourth visit, territories were created by placing minimum convex polygons around Woodlark observations. In addition, a $20 \mathrm{~m}$ buffer was added around each polygon. Pseudo-absence territories (hereafter termed as "absence areas") were then randomly placed in the landscape in areas where no Woodlarks were recorded, varying in size over a similar range as Woodlark territories. The minimum distance between both Woodlark territories and absence areas was $150 \mathrm{~m}$. Absence areas were only placed in vineyards within the mapped study area along the Haardtrand where Woodlark territories occurred to assure comparability.

\section{Environmental variables}

All environmental variables were recorded between mid and end of May 2018. In each of the 52 areas the cover type, vegetation composition and height were measured per vineyard parcel, each parcel representing an individual vineyard with its own management. Within each parcel the management was homogenous, thus making them easily distinguishable. The data were then averaged across each territory or absence area.

Table 1 Habitat characteristics of Woodlark territories $(n=26)$ and absence areas $(n=26)$

\begin{tabular}{llllll}
\hline & \multicolumn{2}{l}{$\begin{array}{l}\text { Woodlark ter- } \\
\text { ritories }\end{array}$} & & \multicolumn{2}{l}{$\begin{array}{l}\text { Absence } \\
\text { areas }\end{array}$} \\
\cline { 2 - 3 } \cline { 6 - 7 } & Mean & SE & & Mean & SE \\
\hline Area (ha) & 4.9 & 0.7 & & 6.1 & 0.3 \\
Number of vineyard parcels & 24.8 & 2.7 & & 21.3 & 1.4 \\
Area of vineyard parcels (ha) & 0.20 & 0.02 & & 0.32 & 0.03 \\
Vegetation cover (\%) & 64.0 & 2.4 & & 68.6 & 2.0 \\
Proportion of forbs & 39.1 & 2.3 & & 27.0 & 1.6 \\
Sward height (cm) & 14.2 & 0.9 & & 19.6 & 1.1 \\
Distance to next built-up area (m) & 553.7 & 61.2 & & 373.3 & 75.6 \\
Arthropod abundance & 69.1 & 4.7 & & 57.5 & 4.7 \\
\hline
\end{tabular}

Presented are means \pm standard errors
The ground vegetation in the studied vineyards is mostly managed in an alternating manner, where every second interrow is tilled during spring while the other inter-row is used for driving. Cultivation schemes with all inter-rows bare or all inter-rows vegetated are less common. Often, the bare inter-rows are sown with annual ground cover mixtures during spring. However, during the breeding period of Woodlarks in spring the ground is still bare. Based on this, on the parcel scale three different ground cover types were identified (Fig. S1): (1) all inter-rows vegetated (100\% cover), (2) every second inter-row vegetated (50\%) and (3) bare soil in all inter-rows ( $0 \%)$. Vegetation cover was then calculated as the average cover per territory. The ground directly beneath the vines was almost always kept free of vegetation, either mechanically or through the use of herbicides.

Furthermore, vegetation composition was recorded as percent cover of forbs and grasses for each different vineyard parcel per area and then averaged. A drop disc (weight $=30 \mathrm{~g}$, diameter $=17.5 \mathrm{~cm}$ ) was used to measure vegetation height in the central green inter-row of each vineyard parcel per area. In each inter-row three measurements were taken, one in the centre and two at the edges of the inter-row. All values from the different vineyard parcels per area were then averaged.

In addition, for each of the 52 areas the distance from the centre to the next built-up area (villages) was measured in GIS (nearest neighbour distance). Single buildings such as farm houses or barns were not considered since they are uncommon in the study area.

\section{Arthropod sampling}

Arthropods as invertebrate prey for Woodlarks were sampled using pitfall traps. At the end of May 2018, we placed four pitfall traps (150 ml volume) filled with ethylene glycol (33\% vol.) in each Woodlark territory and absence area. Two traps per territory and absence area were set up in bare interrows and two in vegetated inter-rows. They were spread over the entire core area of both territories and absence areas with a minimum distance of $40 \mathrm{~m}$ between traps and a distance of at least $15 \mathrm{~m}$ to the edge. Since both woodlark territories and absence areas greatly varied in shape, size and number of individual vineyards, a fully random placement did not seem appropriate. In territories and absence areas that were divided by vineyard paths, the traps were set up more or less in a rectangle, in areas without vineyard paths, they were set up in a line (Fig. S2). The final placement of traps was at random. The traps remained in the field for eight days coinciding with the peak of Woodlark chick provisioning activity (Buehler et al. 2017). In total, 208 traps were set up. Of these traps, only 116 could be retrieved, i.e. 92 traps were 
destroyed or disappeared. However, except for one territory at least one trap per territory remained. The arthropods were then stored in ethanol (70\% vol.), counted and classified into taxa in the lab to get an estimate of prey availability. To account for the different number of traps retrieved per territory, the number of arthropods was divided by the number of intact traps for analyses.

\section{Statistical analyses}

To analyse the incidence of Woodlarks in vineyards we fitted a generalised linear model with binomial errors (R package MASS, Venables and Ripley 2002) with vegetation cover (\%), proportion of dicotyledonous forbs (\%), vegetation height $(\mathrm{cm})$, average arthropod abundance and distances to the next built-up area $(\mathrm{m})$ as explanatory variables. Two more models (1) without vegetation cover and (2) without vegetation cover and arthropod abundance were fitted. The best model was then selected based on Akaike information criterion adjusted for small sample sizes (lowest AICc with $\Delta \mathrm{AICc}>2$ to the second-best model, Table 2). To analyse the dependence of arthropod abundances on vegetation parameters, we further fitted a generalized linear model with quasipoisson errors (R package MASS, Venables and Ripley 2002) with vegetation cover (\%), proportion of dicotyledonous forbs $(\%)$, vegetation height $(\mathrm{cm})$ as explanatory variables. The explanatory variables in all models were uncorrelated and no collinearity (Smith et al. 2009) was detected (function vif from R package usdm, Naimi 2014). All statistical analyses were conducted with $\mathrm{R}$ version 3.4.1 (R Core Team 2017).

\section{Results}

Woodlark territory area ranged from 0.7 to 13.2 ha (mean $=4.9 \mathrm{ha} \pm 3.7 \mathrm{SE})$, the size of absence areas ranged from 3.5 to 10.6 ha (mean $=6.09$ ha $\pm 1.6 \mathrm{SE}$, Table 1$)$. Territory density in the study area was at approximately 0.1 territories/10 ha. The number of vineyard parcels varied between eight and 38 in Woodlark territories and between nine and 56 in absence areas (Table 1; Table S1). Therefore, parcels were small (mean $=0.20 \mathrm{ha} \pm 0.02 \mathrm{SE}$ in Woodlark territories, $0.32 \mathrm{ha} \pm 0.03 \mathrm{SE}$ in absence areas, Table 1).

The best model contained vegetation height, the proportion of dicotyledonous forbs, average arthropod abundance and distances to the next built-up area (Table 2). On a territory scale, we found no effect of vegetation cover on Woodlark incidence in vineyards in our study area, thus this variable was not included in the best model. However, in Woodlark territories the vegetation was about $18 \%$ shorter (mean $14.2 \mathrm{~cm} \pm 0.9 \mathrm{SE}$ vs. $19.6 \mathrm{~cm} \pm 1.1 \mathrm{SE}$ ) and contained $30 \%$ more dicotyledonous forbs than in absence areas (proportion of forbs $39.1 \% \pm 2.3 \mathrm{SE}$ vs. $27 \% \pm 1.6 \mathrm{SE}$ ) (Tables 1 , 3; Fig. 2).

In the 116 pitfall traps retrieved we collected 7467 arthropods. Overall, spiders were the most common taxon (2290 individuals), followed by ants (1728 ind.), beetles (1051 ind.) and flies (954 ind.). Arthropod abundances were 17\% higher in Woodlark territories than in absence areas (mean abundance $69.1 \pm 4.7 \mathrm{SE}$ vs. $57.5 \pm 4.7 \mathrm{SE}$ ) (Tables 1, 3; Fig. 2). In addition, arthropod abundances were not affected by vegetation cover, vegetation composition or height, i.e. the initial null model was the best model (Table S2).

Finally, we found that Woodlarks favoured areas with a larger distance to built-up areas (mean distance $553.7 \mathrm{~m} \pm 61.2 \mathrm{SE}$ vs. $373.3 \mathrm{~m} \pm 75.6 \mathrm{SE}$ ) (Tables 1,3 ; Fig. 2).

Table 3 Generalised linear model showing effects of the proportion of forbs, sward height, distance to next built-up area and arthropod abundance on Woodlark incidence $(N=52)$

\begin{tabular}{lrlrl}
\hline & Estimate & SEM & \multicolumn{1}{l}{$\mathrm{z}$} & $P$ \\
\hline (Intercept) & -3.96 & 2.76 & -1.44 & 0.151 \\
Proportion of forbs & 13.14 & 4.86 & 2.71 & $\mathbf{0 . 0 0 7}$ \\
Sward height & -0.29 & 0.11 & -2.73 & $\mathbf{0 . 0 0 6}$ \\
Arthropod abundance & 0.05 & 0.02 & 1.82 & 0.069 \\
Distance to next village & 0.00 & 0.00 & 2.21 & $\mathbf{0 . 0 2 7}$ \\
\hline
\end{tabular}

Only the variables included in the best model are shown $P$-values $<0.05$ are depicted in bold
Table 2 Model comparison table showing the AICc and $\triangle \mathrm{AICc}$ for the different models

\begin{tabular}{lllll}
\hline Model & Explanatory variables & df & AICc & $\Delta$ AICc \\
\hline $\mathrm{m} 1$ & $\begin{array}{l}\text { Vegetation cover, proportion of forbs, mean height, arthropod } \\
\text { abundance, distance to built-up areas }\end{array}$ & 6 & 47.76 & -2.07 \\
$\mathbf{m} 2$ & $\begin{array}{l}\text { Proportion of forbs, mean height, arthropod abundance, } \\
\text { distance to built-up areas }\end{array}$ & $\mathbf{5}$ & $\mathbf{4 5 . 6 9}$ & +4.85 \\
$\mathrm{~m} 3$ & Proportion of forbs, mean height, distance to built-up areas & 4 & 50.54 & \\
\hline
\end{tabular}

The best model (m2) is shown in bold 
Fig. 2 Relationships between Woodlark territory occupation and $\mathbf{a}$ the proportion of forbs, $\mathbf{b}$ vegetation height, $\mathbf{c}$ distance to built-up areas and $\mathbf{d}$ arthropod availability. Shown is the predicted probability of Woodlark territory occurrence for each explanatory variable ( $y$-axis) and $95 \%$ CIs, based on the best model
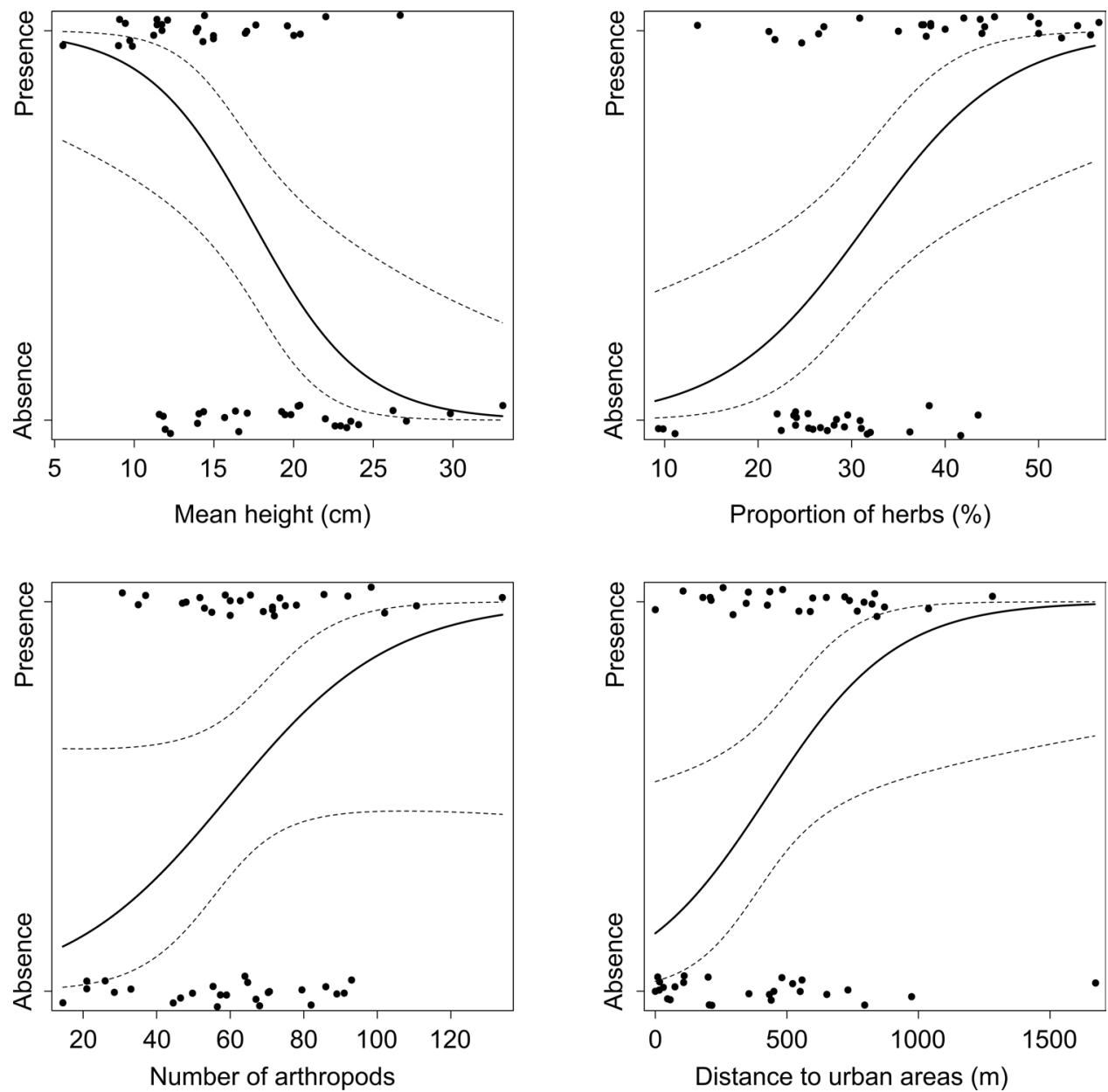

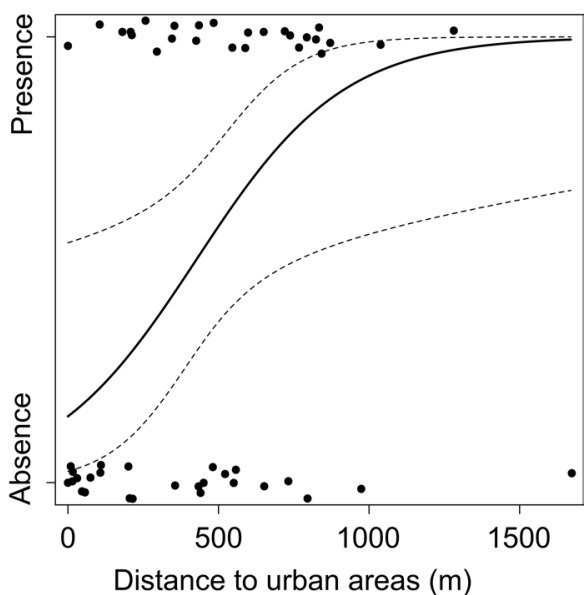

\section{Discussion}

Our results show that Woodlark territory selection is determined by a combination of local and landscapescale factors. On a local scale, Woodlark presence was determined by vineyard management and the resulting structure and composition of the vegetation: while vegetation cover had no influence, the composition and height of the ground cover vegetation as well as arthropod availability influenced Woodlark presence. On a landscape scale, areas with a larger distance to built-up areas were preferred.

Woodlark territories in the study area were comparatively large but still within the range of values found across Europe (Sirami et al. 2011; Arlettaz et al. 2012). On the other hand, with only 0.1 territories/10 ha territory density was relatively low. According to Grunwald (2017) 0.2-1 territories/10 ha can be expected in the Palatinate vineyards. Nevertheless, since we thoroughly surveyed the entire area, we assume that we recorded most territories and conclude that our estimate is reliable. It is thus likely that areas that suit the habitat requirements of Woodlarks in the study area have become scarce. However, alternative explanations for the low territory density we found could be low productivity, e.g. due to high nest predation (Buehler et al. 2017) or low first-year survival rates (Wright et al. 2009). Nevertheless, as outlined below, there are various management options that could help to create the conditions favoured by Woodlarks in vineyards.

\section{Vegetation cover}

Dense swards impede movement, foraging and predator detectability, making short ground vegetation a prerequisite for Woodlark occurrence (Bowden 1990; Vickery et al. 2001). On the other hand, arthropods as an important food source for Woodlarks require vegetation cover to develop (Bosco et al. 2019). Furthermore, Woodlark nests are located in patches of taller vegetation (Snow and Perrins 1998; Buehler et al. 2017). The above indicates a trade-off between the different habitat requirements of Woodlarks. In our study area, most vineyards in both presence and absence areas are vegetated in at least every second inter-row leading to an overall intermediate amount of vegetation cover that is unlikely to be a limiting factor for territory selection. 
This heterogeneity in vegetation cover permits Woodlarks to freely walk on areas of bare soil while gleaning insects from the margin of vegetated areas. Arlettaz et al. (2012) determined an ideal cover of about $55 \%$, which is in line with findings in this study. In Valais, where most vineyards are kept completely bare through herbicide applications, Woodlarks predominantly occur in the few vineyards with vegetation cover (Arlettaz et al. 2012; Buehler et al. 2017; Bosco et al. 2019).

\section{Vegetation height}

While vegetation cover had no influence in our study, nevertheless, territories contained shorter vegetation than pseudo-absence areas, i.e. territories were more likely to occur in areas with shorter swards. As mentioned above, for Woodlarks sward structure is crucial for movement, foraging and predator detectability (Bowden 1990; Vickery et al. 2001; Buehler et al. 2017). Thus, to increase habitat suitability during the breeding season, swards should be kept short in most areas (approx. 10-15 cm). This might be achievable through the sowing or planting of low-growing permanent ground cover mixtures. Regular mowing would not be a suitable option since Woodlarks do not occur in mown grasslands, which might be due to ground nest destruction during mowing (Gedeon et al. 2014). On the contrary, permanent low-growing swards offer several advantages: a reduced mowing frequency would likely increase arthropod availability as a primary food source of Woodlarks and their chicks since mowing is a major cause of arthropod mortality (Humbert et al. 2009). Nest destruction through agricultural machinery and the disturbance of breeding and chick raising would also be minimised. An option that has been suggested to create low swards is the use of plants like Thymus spp. L. (Lamiaceae) or Hieracium pilosella L. (Asteraceae) (Langer et al. 2003), which are native perennials forming dense swards through runners. They are furthermore adapted to the xerothermic conditions that prevail in vineyards and continuously provide floral resources (Koltzenburg et al. 2016). Other welcome side-effects can be the reduction of erosion on steep slopes and the suppression of unwanted, hard to eliminate weeds like Convolvulus arvensis $\mathrm{L}$. (Convolvulaceae) which is the host plant of Hyalestes obsoletus Signoret 1865 (Auchenorrhyncha, Cixiidae), a pathogen-transmitting planthopper species (Maixner et al. 2001; Langer et al. 2003). Nevertheless, swards should be as species rich as possible to increase arthropod abundances and thus suitability for Woodlarks (Bosco et al. 2019).

\section{Vegetation composition}

A higher proportion of forbs in the swards of the vegetated inter-rows increased the probability of Woodlark territory presence. This may be linked with several factors: a sward that is rich in forbs can be expected to be less dense, favouring Woodlark movement as well as arthropod detectability (van Oosten et al. 2014). Furthermore, a higher proportion in forbs is likely to be linked with higher plant diversity, which has been found to be correlated with arthropod diversity and abundance (Siemann et al. 1998; Schaffers et al. 2008; Haddad et al. 2009). In line with this, Woodlarks in the vineyards in Valais were found to prefer areas with a higher plant species richness, which was in turn linked with a higher beetle and spider family richness (Bosco et al. 2019). As mentioned above, herb-rich swards could be created with perennial plant mixtures dominated by low-growing species that provide both floral resources for pollinators (Winter et al. 2018) as well as seeds and arthropod prey for birds (Vickery et al. 2001).

\section{Arthropod availability}

Prey abundances tended to be higher in Woodlark territories than in absence areas, indicating that Woodlarks choose territories within areas of higher prey availability. However, since the sample size was rather low and further decreased through losses during sampling, these results should be treated with caution.

Higher prey abundances in Woodlark territories are in part in agreement with findings in vineyards in Valais (Bosco et al. 2019). While Woodlarks prefer areas with short swards, arthropod communities have frequently been found to be more diverse and abundant in higher grassland swards due to their higher structural complexity (Pöyry et al. 2006, 2009; Gómez et al. 2016). Nevertheless, here we could not detect a correlation between vegetation height and cover and arthropod abundances.

Although we did not record pesticide use in our study, the frequent use of fungicides likely reduces arthropod numbers in vineyards (Attwood et al. 2008) and should thus be kept at a minimum. Grape quality and yields could be secured through an increase in the use of novel fungus-resistant grape varieties that allow a substantial reduction in fungicide applications (Pennington et al. 2018).

\section{Distance to built-up areas}

The higher probability of Woodlark territory presence in areas more distant to built-up areas is likely due to higher disturbance frequencies closer to villages caused by recreational and touristic activities like walking and cycling on 
vineyard paths. It has been shown that in areas that would otherwise be suitable habitat, recreational use can result in a perceived fragmentation for certain species (e.g. Coppes et al. 2017; Jones et al. 2017). This matches the findings of Mallord et al. (2007) who found a lower probability of Woodlark occurrence in areas with recreational use in British heathland sites. An additional explanation could be that Woodlarks avoid predators such as domestic cats and corvids, which are more active near villages (Goszczyński et al. 2009; Thieme et al. 2015). Therefore, further building activity should be avoided in wine-growing areas to preserve Woodlark habitat. This is further supported by a recent study in Valais where Woodlarks were found to avoid areas close to settlements (Bosco et al. 2020).

\section{Conclusion}

The preference of Woodlarks for sparsely vegetated vineyards in the Palatinate contrasts with the situation in Switzerland, where Woodlarks selected vegetation-rich areas within a wine-growing region with a greater overall proportion of bare ground. Thus, management recommendations for Woodlark conservation need to take the regional context into account. We conclude that to promote the Woodlark in our study region but also other wine-growing areas, the vegetation should be kept short to facilitate foraging. This could either be realised through ground cultivation or through the creation of permanent low-growing swards with a high proportion of forbs, which would minimise disturbance and would likely also benefit other taxa like bees (Kratschmer et al. 2019). On the other hand, some small-scaled structural heterogeneity with higher vegetation patches needs to be maintained to fulfill Woodlark nest site requirements (Buehler et al. 2017). To increase the abundance of arthropods, which are the main food source for Woodlark chicks, pesticide applications should be kept at a minimum. Here, the use of novel fungus-resistant wine cultivars could be a solution (Pennington et al. 2018). Finally, we urge to avoid an increase in built-up areas in potential Woodlark habitats.

Supplementary Information The online version contains supplementary material available at https://doi.org/10.1007/s10336-021-01862-4.

Acknowledgements We dedicate this manuscript to Michael Höllgärtner, a great expert and advocate of the regional avifauna who had the original idea for this study but passed away before its completion. We thank Laura Sutcliffe who improved the English and provided helpful comments on the manuscript. We also thank the two anonymous reviewers for their valuable comments. This research did not receive any specific grant from funding agencies in the public, commercial, or not-for-profit sectors.
Author contributions All authors contributed to the study conception and design. Material preparation, data collection and analysis were performed by Pascal Aloisio, Verena Rösch and Martin H Entling. The first draft of the manuscript was written by Verena Rösch and all authors commented on previous versions of the manuscript. All authors read and approved the final manuscript.

Funding Open Access funding enabled and organized by Projekt DEAL. This research did not receive any specific grant from funding agencies in the public, commercial, or not-for-profit sectors.

Availability of data and material (datatransparency) The datasets generated and analysed during the current study are available from the corresponding author on reasonable request.

\section{Compliance with ethical standards}

Conflict of interest No conflict of interests.

Open Access This article is licensed under a Creative Commons Attribution 4.0 International License, which permits use, sharing, adaptation, distribution and reproduction in any medium or format, as long as you give appropriate credit to the original author(s) and the source, provide a link to the Creative Commons licence, and indicate if changes were made. The images or other third party material in this article are included in the article's Creative Commons licence, unless indicated otherwise in a credit line to the material. If material is not included in the article's Creative Commons licence and your intended use is not permitted by statutory regulation or exceeds the permitted use, you will need to obtain permission directly from the copyright holder. To view a copy of this licence, visit http://creativecommons.org/licenses/by/4.0/.

\section{References}

Arlettaz R, Maurer ML, Mosimann-Kampe P et al (2012) New vineyard cultivation practices create patchy ground vegetation, favouring Woodlarks. J Ornithol 153:229-238. https://doi.org/10.1007/ s10336-011-0737-7

Attwood SJ, Maron M, House APN, Zammit C (2008) Do arthropod assemblages display globally consistent responses to intensified agricultural land use and management? Glob Ecol Biogeogr 17:585-599. https://doi.org/10.1111/j.1466-8238.2008.00399.x

Bauer H-G, Bezzel E, Fiedler W (2005) Das Kompendium der Vögel Mitteleuropas, 2nd edn. AULA-Verlag, Wiebelsheim

Bosco L, Arlettaz R, Jacot A (2019) Ground greening in vineyards promotes the Woodlark Lullula arborea and their invertebrate prey. J Ornithol 160:799-811. https://doi.org/10.1007/s1033 6-019-01666-7

Bosco L, Cushman SA, Wan HY et al (2020) Fragmentation effects on woodlark habitat selection depend on habitat amount and spatial scale. Anim Conserv. https://doi.org/10.1111/acv.12604

Bötsch Y, Tablado Z, Jenni L (2017) Experimental evidence of human recreational disturbance effects on bird-territory establishment. Proc R Soc B Biol Sci. https://doi.org/10.1098/rspb.2017.0846

Bötsch Y, Tablado Z, Scherl D et al (2018) Effect of recreational trails on forest birds: Human presence matters. Front Ecol Evol 6:1-10. https://doi.org/10.3389/fevo.2018.00175

Bowden CGR (1990) Selection of foraging habitats by woodlarks (Lullula arborea) nesting in pine plantations. J Appl Ecol 27:410-419

Buehler R, Bosco L, Arlettaz R, Jacot A (2017) Nest site preferences of the Woodlark (Lullula arborea) and its association with 
artificial nest predation. Acta Oecologica 78:41-46. https://doi. org/10.1016/j.actao.2016.12.004

Coppes J, Ehrlacher J, Thiel D et al (2017) Outdoor recreation causes effective habitat reduction in capercaillie Tetrao urogallus: a major threat for geographically restricted populations. J Avian Biol 48:1583-1594. https://doi.org/10.1111/jav.01239

European Commission (2007) The use of plant protection products in the European union - Data 1992-2003. EUROSTAT, Official Publications of the European Community, Luxembourg

Foley JA, Defries R, Asner GP et al (2005) Global consequences of land use. Science 309:570-574. https://doi.org/10.1126/scien ce. 1111772

Gedeon K, Grüneberg C, Mitschke A et al (2014) Atlas Deutscher Brutvogelarten. Atlas of German Breeding Birds, Stiftung Vogelmonitoring Deutschland und Dachverband Deutscher Avifaunisten, Münster

Gómez JE, Lohmiller J, Joern A (2016) Importance of vegetation structure to the assembly of an aerial web-building spider community in North American open grassland. J Arachnol 44:28-35. https:// doi.org/10.1636/p14-58.1

Goszczyński J, Krauze D, Gryz J (2009) Activity and exploration range of house cats in rural areas of central Poland. Folia Zool 58:363-371

Grüneberg C, Bauer H-G, Haupt H et al (2015) Rote Liste der Brutvögel Deutschlands. 5. Fassung Berichte zum Vogelschutz 52:19-67

Grunwald T (2017) Heidelerche Lullula arborea (LINNAEUS, 1758). In: Dietzen C et al. Die Vogelwelt von Rheinland-Pfalz. Band 4 Singvögel (Passeriformes). Fauna und Flora in Rheinland-Pfalz, Beiheft 49, Landau, pp 218-228

Haddad NM, Crutsinger GM, Gross K et al (2009) Plant species loss decreases arthropod diversity and shifts trophic structure. Ecol Lett 12:1029-1039. https://doi.org/10.111 $1 / \mathrm{j} .1461-0248.2009 .01356 . x$

Hallmann CA, Sorg M, Jongejans E et al (2017) More than 75 percent decline over 27 years in total flying insect biomass in protected areas. PLoS ONE. https://doi.org/10.1371/journal.pone.0185809

Hanspach J, Abson DJ, French Collier N et al (2017) From trade-offs to synergies in food security and biodiversity conservation. Front Ecol Environ 15:489-494. https://doi.org/10.1002/fee.1632

Humbert J-Y, Ghazoul J, Walter T (2009) Meadow harvesting techniques and their impacts on field fauna. Agric Ecosyst Environ 130:1-8. https://doi.org/10.1016/j.agee.2008.11.014

International BirdLife (ed) (2004) Birds in Europe: Population Estimates, Trends and Conservation Status. BirdLife I, BirdLife International, Cambridge

International BirdLife (ed) (2015) Lullula arborea (Wood Lark) European Red List of Birds. Office for Official Publications of the European Communities, Luxembourg

Jones AS, Anderson JJ, Dickson BG et al (2017) Off-highway vehicle road networks and kit fox space use. J Wildl Manage 81:230-237. https://doi.org/10.1002/jwmg.21204

Kassemeyer HH, Berkelmann-Löhnertz B (2009) Fungi of Grapes. Biology of Microorganisms on Grapes, in Must and in Wine. Springer, Berlin, pp 61-87

Kolb S, Uzman D, Leyer I et al (2020) Differential effects of seminatural habitats and organic management on spiders in viticultural landscapes. Agric Ecosyst Environ 287:106695. https://doi. org/10.1016/j.agee.2019.106695

Koltzenburg M, Parolly G, Rohwer JG et al (2016) Schmeil-Fitschen - Die Flora Deutschlands und angrenzender Länder, 96th edn. Quelle \& Meyer, Wiebelsheim

Kratschmer S, Pachinger B, Schwantzer M et al (2019) Response of wild bee diversity, abundance, and functional traits to vineyard inter-row management intensity and landscape diversity across Europe. Ecol Evol 9:4103-4115. https://doi.org/10.1002/ ece3.5039

Langer M, Darimont H, Maixner M (2003) Control of phytoplasma vectors in organic viticulture. IOBC/wprs Bull 26:197-202

Leather SR (2018) "Ecological Armageddon" - more evidence for the drastic decline in insect numbers. Ann Appl Biol 172:1-3. https ://doi.org/10.1111/aab.12410

Maixner M, Darimont H, Mohr HD (2001) Studies on the transmission of bois noir to weeds and potential ground-cover plants by Hyalesthes obsoletus Signoret (Auchenorrhyncha: Cixiidae). IOBC/ wprs Bull 24:249-251

Mallord JW, Dolman PM, Brown AF, Sutherland WJ (2007) Linking recreational disturbance to population size in a ground-nesting passerine. J Appl Ecol 44:185-195. https://doi.org/10.111 1/j.1365-2664.2006.01242.x

Maslo B, Leu K, Pover T et al (2018) Managing birds of conservation concern on sandy shores: How much room for future conservation actions is there? Ecol Evol 8:10976-10988. https://doi. org/10.1002/ece3.4564

Matson PA, Parton WJ, Power AG, Swift MJ (1997) Agricultural intensification and ecosystem properties. Science 277:504-509. https ://doi.org/10.1126/science.277.5325.504

Møller AP (2019) Parallel declines in abundance of insects and insectivorous birds in Denmark over 22 years. Ecol Evol 9:6581-6587. https://doi.org/10.1002/ece3.5236

Naimi B (2014) usdm: Uncertainty analysis for species distribution models, R package version 1.1-12, http://usdm.r-forge.r-proje ct.org/, http://r-gis.net

Pennington T, Reiff JM, Theiss K et al (2018) Reduced fungicide applications improve insect pest control in grapevine. Biocontrol 63:687-695. https://doi.org/10.1007/s10526-018-9896-2

Pithon JA, Beaujouan V, Daniel H et al (2016) Are vineyards important habitats for birds at local or landscape scales? Basic Appl Ecol 17:240-251. https://doi.org/10.1016/j.baae.2015.12.004

Pöyry J, Luoto M, Paukkunen J et al (2006) Different responses of plants and herbivore insects to a gradient of vegetation height: an indicator of the vertebrate grazing intensity and successional age. Oikos 3:401-412

Pöyry J, Paukkunen J, Heliölä J, Kuussaari M (2009) Relative contributions of local and regional factors to species richness and total density of butterflies and moths in semi-natural grasslands. Oecologia 160:577-587. https://doi.org/10.1007/s00442-009-1328-7

R Core Team (2017) R: A Language and Environment for Statistical Computing

Rollan À, Hernández-Matías A, Real J (2019) Organic farming favours bird communities and their resilience to climate change in Mediterranean vineyards. Agric Ecosyst Environ 269:107-115. https ://doi.org/10.1016/j.agee.2018.09.029

Sala OE, Chapin FS, Armesto JJ et al (2000) Global biodiversity scenarios for the year 2100. Science 287:1770-1774

Schaffers AP, Raemakers IP, Syorka KV, ter Braak CJF (2008) Arthropod assemblages are best predicted by plant species composition. Ecology 89:782-794

Siemann E, Tilman D, Haarstad J, Ritchie M (1998) Experimental tests of the dependence of arthropod diversity on plant diversity. Am Nat 152:738-750. https://doi.org/10.1086/286204

Simon L, Braun M, Grunwald T et al (2014) Rote Liste der Brutvögel in Rheinland-Pfalz. Ministerium für Umwelt, Landwirtschaft, Ernährung, Weinbau und Forsten Rheinland-Pfalz, Mainz

Sirami C, Brotons L, Martin JL (2011) Woodlarks Lullula arborea and landscape heterogeneity created by land abandonment. Bird Study 58:99-106. https://doi.org/10.1080/00063657.2010.532861

Smith AC, Koper N, Francis CM, Fahrig L (2009) Confronting collinearity: comparing methods for disentangling the effects of habitat 
loss and fragmentation. Landsc Ecol 24:1271-1285. https://doi. org/10.1007/s10980-009-9383-3

Snow DW, Perrins CM (1998) The birds of the western Palearctic: Passerines. Vol. 2, Concise ed. Oxford University Press, Oxford

Südbeck P, Andretzke H, Fischer S, et al (2005) Methodenstandards zur Erfassung der Brutvögel Deutschlands. Radolfzell

Thieme JL, Rodewald AD, Brown J et al (2015) Linking grassland and early successional bird territory density to predator activity in Urban parks. Nat Areas J 35:515-532. https://doi. org/10.3375/043.035.0404

van Oosten HH, van den Burg AB, Versluijs R, Siepel H (2014) Habitat selection of brood-rearing Northern Wheatears Oenanthe oenanthe and their invertebrate prey. Ardea 102:61-69. https:// doi.org/10.5253/078.102.0111

Venables WN, Ripley BD (2002) Modern applied statistics with S, 4th edn. Springer, New York

Verhulst J, Báldi A, Kleijn D (2004) Relationship between land-use intensity and species richness and abundance of birds in Hungary. Agric Ecosyst Environ 104:465-473. https://doi.org/10.1016/j. agee.2004.01.043
Vickery JA, Tallowin JR, Feber RE et al (2001) The management of lowland neutral grasslands in Britain: Effects of agricultural practices on birds and their food resources. J Appl Ecol 38:647-664. https://doi.org/10.1046/j.1365-2664.2001.00626.x

Viers JH, Williams JN, Nicholas KA et al (2013) Vinecology: Pairing wine with nature. Conserv Lett 6:287-299. https://doi. org/10.1111/conl.12011

Winter S, Bauer T, Strauss P et al (2018) Effects of vegetation management intensity on biodiversity and ecosystem services in vineyards: A meta-analysis. J Appl Ecol 55:2484-2495. https://doi. org/10.1111/1365-2664.13124

Wright LJ, Hoblyn RA, Green RE et al (2009) Importance of climatic and environmental change in the demography of a multi-brooded passerine, the woodlark Lullula arborea. J Anim Ecol 78:11911202. https://doi.org/10.1111/j.1365-2656.2009.01582.x

Publisher's Note Springer Nature remains neutral with regard to jurisdictional claims in published maps and institutional affiliations. 